\title{
Profil Hematologi dan Pemantauan Dosis Petugas Radiologi di Rumah Sakit Penyakit Infeksi (RSPI) Prof. Dr. Sulianti Saroso Tahun 2014-2015
}

\author{
Hematological Profile and Dose Monitoring at Officer Radiology in \\ Infectious Disease Hospital Prof. Dr. Sulianti Saroso (2014-2015)
}

\author{
Jahiroh ${ }^{*}$, Nunung Hendrawati, Maya Marinda Montain \\ RSPI Prof. Dr. Sulianti Saroso, Kementerian Kesehatan Republik Indonesia
}

*Korespondensi Penulis :

Jahiroh

Email : jahiroh1974@yahoo.com

\begin{abstract}
Abstrak
Latar belakang : Petugas radiologi mempunyai risiko untuk terpapar radiasi. Pemantauan kesehatan dan dosis para petugas radiologi wajib dilakukan untuk mengidentifikasi adanya gejala awal atau tanda kerusakan awal akibat paparan radiasi dan untuk menjamin keselamatan dan kesehatan petugas radiologi. Penelitian ini bertujuan untuk meningkatkan kewaspadaan terhadap risiko paparan radiasi pada petugas radiologi berdasarkan hasil pemeriksaan hematologi dan pemantauan dosis.

Metode : Kajian ini menggunakan desain deskriptif dengan metode potong lintang. Subyek yang digunakan dalam kajian ini terdiri dari ahli radiologi, radiografer dan petugas administrasi yang bekerja di Instalasi Radiologi, RSPI Prof. Dr. Sulianti Saroso periode 2014-2015. Data yang digunakan yaitu data sekunder dari hasil pemeriksaan kesehatan berkala tahun 2014-2015, berupa data karakteristik demografi dan pemeriksaan laboratorium. Hasil pengukuran dosis radiasi dari laboratorium pemantauan dosis perorangan - Balai Pengamanan Fasilitas Kesehatan dan Pusat Teknologi Keselamatan dan Metrologi Radiasi - Badan Tenaga Nuklir Nasional (BATAN).

Hasil : Jumlah petugas radiologi laki-laki sama dengan jumlah petugas perempuan, sebanyak $58,4 \%$ petugas berusia $31-40$ tahun, $75 \%$ petugas berpendidikan DIII radiologi, 33,3\% petugas dengan lama kerja 11-15 tahun. Hasil pemeriksaan kadar $\mathrm{Ht}$, leukosit, dan LED menunjukkan semua petugas masih dalam batas normal. Petugas yang mempunyai kadar $\mathrm{Hb}$ rendah meningkat menjadi 33,3\% pada tahun 2015 dari tahun 2014 (25\%). Petugas yang mengalami anemia normositik meningkat dari 16,5\% (2014) menjadi $25 \%$ (2015). Sebanyak $16,6 \%$ petugas mempunyai kadar serum besi yang rendah, sebanyak $25 \%$ petugas mempunyai jumlah retikulosit yang rendah. Hasil pemantauan dosis radiasi pada tahun 2014 dan 2015 menunjukkan semua petugas radiologi masih dibawah Nilai Batas Dosis.

Kesimpulan : Secara keseluruhan hasil pemeriksaan hematologi dan pemantauan dosis petugas radiologi masih dalam batas normal.
\end{abstract}

Kata kunci: Profil hematologi, Pemantaun dosis, Petugas radiologi

\begin{abstract}
Background : The officer radiology at risk for exposure to radiation. Health monitoring and dose the radiology staff must be conducted to identify the presence of early symptoms or signs of early damage due to exposure to radiation and to ensure the safety and health of radiology staff. This study aims to increase awareness of the risks of radiation exposure in radiology staff based on the results of hematology and dose monitoring.

Methods : The study used a descriptive design with cross sectional method. The subjects used in this study consists of radiologists, radiographers and administrators who work in Radiology, Prof. RSPI Dr. Sulianti Saroso period 2014-2015. The data used is secondary data from periodic health examination results year 2014-2015, in the form of data on demographic characteristics and laboratory tests. The results of the laboratory measurement of radiation dose monitoring individual dose - Safety Center Health
\end{abstract}


Facilities and Technology Center Safety and Radiation Metrology - National Nuclear Energy Agency (BATAN).

Results : The number of male officers radiology equal to the number of women officers, as many as $58.4 \%$ of $31-40$-year-old clerk, $75 \%$ of the officers educated DIII radiology, $33.3 \%$ of the officers working with 11-15 years old. Examination results hematocrit levels, leukocytes, and LEDs indicate all the officers are still within normal limits. Officers who have low Hb level increased to 33.3\% in 2015 from 2014 (25\%). Officers who are anemic normositik increased from 16.5\% (2014) to 25\% (2015). A total of $16.6 \%$ of the officers had serum iron levels are low, as many as $25 \%$ of the officers had a low reticulocyte count. Radiation dose monitoring results in 2014 and 2015 shows all radiology staff is still below the dose limit value.

Conclusion : Overall results of the monitoring of hematology and radiology staff doses are within normal limits.

Keywords: Hematological profile, Dose monitoring, Radiology staff

Pendahuluan

Petugas radiologi mempunyai risiko terpapar radiasi, dengan efek biologi utama yaitu kerusakan sistem hemopoetik dan limfatik yang dapat menimbulkan kerusakan somatik dan kerusakan genetik. Risiko kerusakan somatik berupa penyakit kanker akan dialami langsung oleh orang yang sel somatiknya terkena penyinaran. Risiko dari kerusakan genetik tidak dialami oleh yang bersangkutan, melainkan keturunan orang tersebut yang akan untuk menderita cacat genetis. Indikator hematopoitik meliputi hitung limfosit absolut, neutrofil, platelet dan sel darah merah. ${ }^{1,2,3}$

Hasil penelitian The International Nuclear Workers Study (INWORKS) menunjukkan hubungan yang signifikan antara peningkatan dosis radiasi dengan risiko sakit kanker. Risiko kematian akibat kanker meningkat sekitar 5\% per 100 mGy. Penelitian tersebut dilakukan terhadap lebih dari 300.000 pekerja nuklir di Perancis, Inggris, dan USA selama periode waktu antara 1943 2005.4

Berdasarkan hasil penelitian sebelumnya terhadap pekerja Divisi Radiologi RS Dr. Kariadi Semarang menunjukan perbedaan indikator hematopeitik yang bermakna antara pekerja kontak lansung dan non kontak lansung. Secara terperinci dapat dijelaskan bahwa ada perbedaan yang bermakna jumlah leukosit antara pekerja radiasi kontak langsung dan pekerja radiasi non kontak langsung $(p=0,0371)$. Ada perbedaan bermakna hitung jenis leukosit yaitu pada eosinofil ( $p=0,038$ ), segmen $(p=0.036)$, limfosit $(p=0,049)$ dan monosit $(p=0,003) 3)$. Ada pengaruh signifikan antara radiasi terhadap trombosit $(p=0,029)$, segmen $(P=-0,052)$ dan monosit $(p=0.02)$ pada pekerja kontak langusng dengan pekerja non kontak langsung. ${ }^{6}$

Pemantauan kesehatan dan pengawasan dosis radiasi secara periodik terhadap para petugas radiologi wajib dilakukan oleh rumah sakit, dengan tujuan memastikan keadaan 
kesehatan petugas radiologi agar dapat melaksanakan tugasnya. Untuk itu disusun profil kesehatan petugas radiologi, yang meliputi yang meliputi profil hematologi dan dosis radiasi. Kajian ini bertujuan meningkatkan kewaspadaan terhadap risiko paparan radiasi pada petugas radiologi di Rumah Sakit Penyakit Infeksi (RSPI) Prof. Dr. Sulianti Saroso.

\section{Metode}

Kajian ini menggunakan desain deskriptif dengan metode potong lintang. Subyek yang digunakan dalam kajian ini terdiri dari ahli radiologi, radiografer dan petugas administrasi yang bekerja di Instalasi Radiologi, RSPI Prof. Dr. Sulianti Saroso periode 2014-2015. Data yang digunakan yaitu data sekunder dari hasil pemeriksaan kesehatan berkala tahun 2014-2015, berupa data karakteristik demografi dan pemeriksaan laboratorium yang terdiri dari pemeriksaan darah lengkap $(\mathrm{Hb}, \mathrm{Ht}$, Trombosit, Eritrosit, Leukosit, LED, hitung jenis leukosit), morfologi darah tepi, fungsi hati (SGOT, SGPT), fungsi ginjal (ureum, kreatinin), retikulosit, serum besi dan Total Iron Binding Capacity (TIBC). Data hasil pengukuran dosis radiasi menggunakan data sekunder dari laboratorium Pemantauan Dosis Perorangan - Balai Pengamanan Fasilitas Kesehatan dan Pusat Teknologi Keselamatan dan Metrologi
Radiasi - Badan Tenaga Nuklir Nasional (BATAN).

$$
\text { Data diolah menggunakan }
$$

Software Microsoft Excel versi 2007. Persetujuan etik didapatkan dari Komisi Etik RSPI Prof. Dr. Sulianti Saroso.

\section{Hasil}

Petugas radiologi yang menjadi subyek pada kajian ini berjumlah 12 orang, dimana sebagian besar berusia $31-40$ tahun yaitu 7 orang $(58,4 \%)$ berpendidikan D3 yaitu 9 orang $(75 \%)$ dengan lama kerja 11-15 tahun yaitu 4 orang (33.3\%). Proporsi jenis kelamin antara laki-laki dan perempuan sama. Keseluruhan karakteristik dapat dilihat pada Tabel 1.

Tabel 1. Karakteristik Petugas Radiologi di Instalasi Radiologi tahun 20142015

\begin{tabular}{llc}
\hline Karakteristik & $\mathrm{n}$ & $\%$ \\
\hline Jenis Kelamin & & \\
Laki-Laki & 6 & 50 \\
Perempuan & 6 & 50 \\
Usia & & \\
$21-30$ thn & 1 & 5,3 \\
31-40 thn & 7 & 58,4 \\
$41-50$ thn & 1 & 5,3 \\
51-60 thn & 3 & 25 \\
Pendidikan & & \\
S2 & 2 & 16,7 \\
D3 & 9 & 75 \\
SLTA & 1 & 8,3 \\
Lama kerja & & \\
1-5 tahun & 3 & 25 \\
6-10 tahun & 3 & 25 \\
11-15 tahun & 4 & 33.33 \\
16-20 tahun & 0 & 0 \\
21-30 tahun & 2 & 16.67 \\
\hline
\end{tabular}


Hasil pemeriksaan darah lengkap terutama pada pemeriksaan kadar $\mathrm{Ht}$, leukosit, dan LED semua petugas menunjukkan masih dalam batas normal. Untuk hasil pemeriksaan $\mathrm{Hb}$, petugas yang mempunyai kadar $\mathrm{Hb}$ rendah pada tahun 2014 sebanyak 3 orang dan bertambah menjadi 4 orang pada tahun 2015. Untuk pemeriksaan morfologi darah tepi, menunjukkan bahwa pada tahun 2014 ditemukan dua orang mengalami anemia normositik dan bertambah menjadi tiga orang pada tahun 2015, seperti dapat dilihat pada tabel 2.

Seluruh petugas radiologi memiliki hasil pemeriksaan eosinofil yang tidak normal pada tahun 2014 dan 2015. Untuk pemeriksaan eritrosit, jumlah pekerja yang memiliki nilai eritrosit rendah, bertambah dari 1 orang di tahun 2014 menjadi 2 orang di tahun 2015 (Tabel 3).

Tabel 2. Hasil Pemeriksaan Kadar Hb dan MDT Petugas Radiologi di Instalasi Radiologi Tahun 2014-2015

\begin{tabular}{lccccccccc}
\hline & \multicolumn{4}{c}{ Tahun 2014} & \multicolumn{3}{c}{ Tahun 2015 } \\
\cline { 2 - 10 } Variabel & \multicolumn{2}{c}{ Laki-laki } & \multicolumn{2}{c}{ Perempuan } & \multicolumn{2}{c}{ Laki-laki } & \multicolumn{2}{c}{ Perempuan } \\
\cline { 2 - 10 } & $\mathrm{n}$ & $\%$ & $\mathrm{n}$ & $\%$ & $\mathrm{n}$ & $\%$ & $\mathrm{n}$ & $\%$ \\
\hline Hemoglobin & 1 & 8.3 & 2 & 16.7 & 2 & 16.7 & 2 & 16.7 \\
- Rendah & Normal & 5 & 41.7 & 4 & 33.3 & 4 & 33.3 & 4 & 33.3 \\
Morfologi Darah Tepi & & & & & & & & \\
- Normal & 6 & 100 & 4 & 66.7 & 5 & 83.3 & 4 & 66.7 \\
- Anemia Normositik & 0 & 0 & 2 & 33.3 & 1 & 16.7 & 2 & 33.3 \\
\hline
\end{tabular}

Tabel 3. Hasil Pemeriksaan Hitung Jenis Leukosit Petugas Radiologi di Instalasi Radiologi Tahun 2014-2015

\begin{tabular}{|c|c|c|c|c|c|c|c|c|}
\hline \multirow{3}{*}{ Variabel } & \multicolumn{4}{|c|}{ Tahun 2014} & \multicolumn{4}{|c|}{ Tahun 2015} \\
\hline & \multicolumn{2}{|c|}{ Normal } & \multicolumn{2}{|c|}{ Tdk Normal } & \multicolumn{2}{|c|}{ Normal } & \multicolumn{2}{|c|}{ Tdk Normal } \\
\hline & $\mathrm{n}$ & $\%$ & $\mathrm{n}$ & $\%$ & $\mathrm{n}$ & $\%$ & $\mathrm{n}$ & $\%$ \\
\hline \multicolumn{9}{|l|}{$\begin{array}{l}\text { Hitung Jenis } \\
\text { Leukosit }\end{array}$} \\
\hline - basofil & 12 & 100 & 0 & 0 & 10 & 100 & 0 & 0 \\
\hline - eosinofil & 0 & 0 & 12 & 100 & 0 & 0 & 10 & 100 \\
\hline - batang & 7 & 58.3 & 5 & 41.7 & 7 & 70 & 3 & 30 \\
\hline - segmen & 11 & 91.7 & 1 & 8.3 & 10 & 100 & 0 & 0 \\
\hline - $\quad \operatorname{limfosit}$ & 11 & 91.7 & 1 & 8.3 & 9 & 90 & 1 & 10 \\
\hline - monosit & 12 & 100 & 0 & 0 & 10 & 100 & 0 & 0 \\
\hline \multicolumn{9}{|l|}{ Eritrosit } \\
\hline - Laki-laki & 6 & 50 & 0 & 0 & 3 & 30 & 2 & 20 \\
\hline - Perempuan & 5 & 41.7 & 1 & 8.3 & 5 & 50 & 0 & 0 \\
\hline
\end{tabular}


Hasil pemeriksaan LED petugas radiologi laki-laki di tahun 2014 dan 2015 dalam batas normal. Untuk pekerja radiologi perempuan, jumlah pekerja yang memiliki nilai LED tinggi, meniggkat dari 1 orang di tahun 2014 menjadi 2 orang di tahun 2015. Hasil pemeriksaan SGOT, pada tahun 2014 dan 2015 menunjukkan terdapat dua petugas yang mempunyai kadar SGOT yang tinggi. Hasil pemeriksaan SGPT, pada tahun 2014 menunjukkan terdapat 3 petugas radiologi yang mempunyai kadar SGPT yang tinggi dan pada tahun 2015 , terdapat 4 orang petugas yang mempunyai kadar SGPT yang tinggi (Tabel 4).

Tabel 4. Hasil Pemeriksaan LED ,SGOT dan SGPT Petugas Radiologi di Instalasi Radiologi tahun 2014-2015

\begin{tabular}{lcccc}
\hline Pemeriksaan & \multicolumn{2}{c}{ Tahun 2014 } & \multicolumn{2}{c}{ Tahun 2015 } \\
\cline { 2 - 5 } & $\mathrm{n}$ & $\%$ & $\mathrm{n}$ & $\%$ \\
\hline LED & 1 & 16.7 & 2 & 22.2 \\
- Tinggi & 1 & 16.7 & 2 & 22.2 \\
- Normal & 5 & 83.3 & 7 & 77.8 \\
SGOT & & & & \\
- Tinggi & 2 & 20 & 2 & 20 \\
- Normal & 8 & 80 & 8 & 80 \\
SGPT & & & & \\
- Tinggi & 3 & 30 & 4 & 50 \\
- Normal & 7 & 70 & 4 & 50 \\
\hline
\end{tabular}

Pemeriksaan fungsi ginjal yang terdiri dari pemeriksaan ureum dan kreatinin, dilakukan hanya pada tahun 2015 terhadap 11 petugas. Hasil pemeriksaan ureum dan kreatinin menunjukkan semua petugas radiologi mempunyai kadar ureum dan kreatini dalam batas normal, kadar ureum (10$50 \mathrm{mg} / \mathrm{dl}$ ) dan kadar kreatinin normal (laki-laki: 0,7-1,6 mg/dl, perempuan: 0,5$0,9 \mathrm{mg} / \mathrm{dl})$.

Pemeriksaan retikulosit dilakukan terhadap 12 petugas di tahun 2015 dan hasilnya menunjukkan semua petugas masih berada dalam batas normal. (kadar retikulosit: 0.5 - $1.5 \%$ ). Pemeriksaan kadar TIBC dan Serum Besi (SI) yang dilakukan terhadap 11 petugas radiologi di tahun 2015 menunjukan hasil pemeriksaan TIBC masih dalam batas normal. Hasil pemeriksaan serum besi menunjukkan satu petugas laki-laki dan satu petugas perempuan mempunyai kadar serum besi yang rendah, seperti ditunjukkan pada Gambar 1.

Hasil pemeriksaan dosis perorangan seluruh petugas radiologi di tahun 2014 dan 2015 masih di bawah Nilai Batas Dosis (20 mSv/tahun). Pemantauan dosis dilakukan dengan menggunakan film badge (2014) dan lencana TLD (Termoluminisensi Dosimeter) tahun 2015. Keseluruhan hasil disajikan pada tabel 7 . 

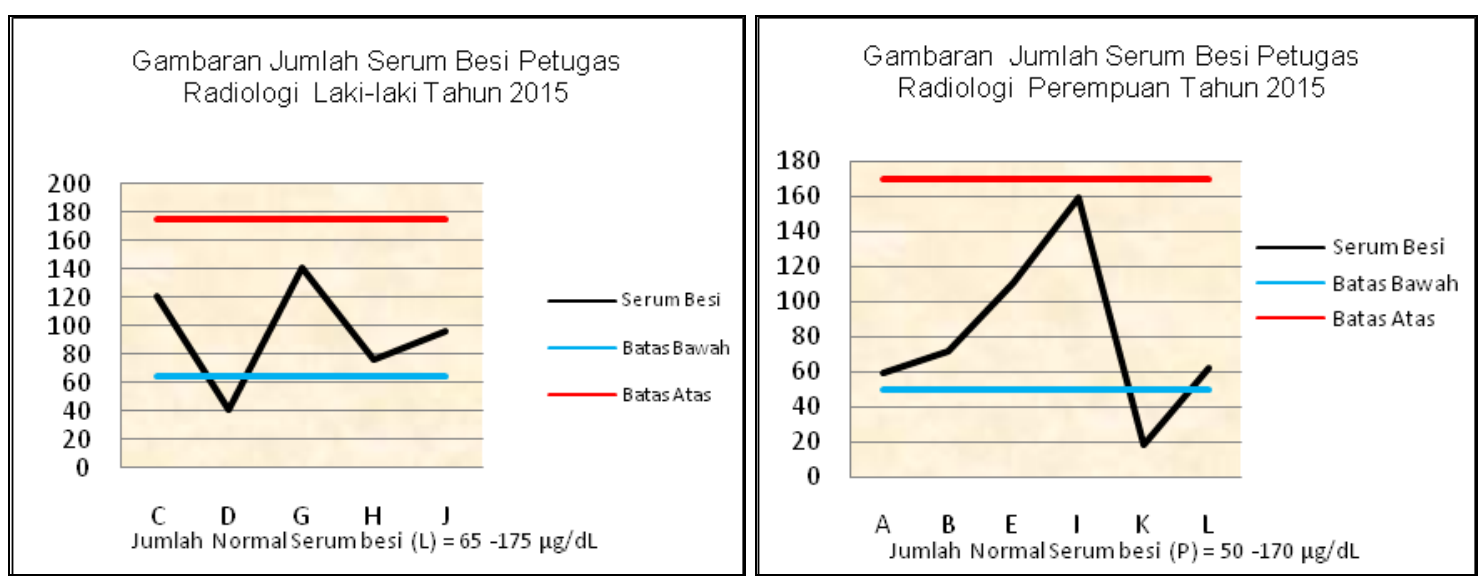

Gambar 1. Hasil Pemeriksaan Jumlah Serum Besi Petugas Radiologi di Instalasi Radiologi Tahun 2014-2015 di RSPI Prof. Dr. Sulianti Saroso

Tabel 7. Hasil Pemantauan Dosis pada Petugas Radiologi RSPI Sulianti Saroso Tahun 2015-

\begin{tabular}{|c|c|c|c|}
\hline \multirow[t]{2}{*}{$\begin{array}{l}\text { Nama } \\
\text { Petugas }\end{array}$} & \multirow{2}{*}{$\begin{array}{l}\text { Jumlah dosis pertahun } \\
2014 \text { (menggunakan } \\
\text { film badge) }\end{array}$} & \multicolumn{2}{|c|}{$\begin{array}{c}\text { Hasil Pemeriksaan Dosis Perorangan dengan } \\
\text { Lencana TLD }\end{array}$} \\
\hline & & $\begin{array}{l}\text { Periode April - Juni } \\
2015\end{array}$ & $\begin{array}{l}\text { Periode Oktober - } \\
\text { Desember } 2015\end{array}$ \\
\hline A & $1.1 \mathrm{mSv}$ & 0 & 0 \\
\hline B & $1.1 \mathrm{mSv}$ & $0,06 \pm 16 \%$ & $0,07 \pm 15 \%$ \\
\hline C & $1.1 \mathrm{mSv}$ & 0 & 0 \\
\hline D & $1.1 \mathrm{mSv}$ & $0,05 \pm 17 \%$ & 0 \\
\hline$E$ & $1.1 \mathrm{mSv}$ & $0,06 \pm 16 \%$ & 0 \\
\hline $\mathrm{F}$ & $1.1 \mathrm{mSv}$ & 0 & 0 \\
\hline G & $1.1 \mathrm{mSv}$ & 0 & 0 \\
\hline $\mathrm{H}$ & $1.1 \mathrm{mSv}$ & $0,06 \pm 16 \%$ & 0 \\
\hline 1 & $1.1 \mathrm{mSv}$ & 0 & 0 \\
\hline$J$ & $1.1 \mathrm{mSv}$ & 0 & 0 \\
\hline K & $1.1 \mathrm{mSv}$ & $0,06 \pm 16 \%$ & 0 \\
\hline L & $1.1 \mathrm{mSv}$ & 0 & 0 \\
\hline
\end{tabular}

\section{Pembahasan}

Jumlah petugas radiologi yang menjadi subyek pada kajian ini yaitu 12 orang, dengan jumlah petugas laki-laki sama dengan jumlah petugas perempuan. Hal ini berbeda dengan hasil penelitian Eddi Suhaedi Sulaeman bahwa jumlah petugas radiologi laki-laki di Rumah Sakit Kariadi Semarang lebih banyak $(61,29 \%)$ dibandingkan dengan perempuan. $^{6}$

Usia rata-rata petugas radiologi di RSPI Prof. Dr. Sulianti Saroso yaitu 41 tahun dan sebagian besar (58,3\%) berusia antara 31-40 tahun. Hal ini sesuai dengan penelitian yang 
dilakukan oleh Mayerni, dkk (2013) bahwa rata-rata umur responden adalah 35 tahun, dan sebagian besar umur responden berusia 25 tahun. $^{6}$ Dan sesuai dengan PERKA BAPETEN No. 4 tahun 2013 bahwa pimpinan rumah sakit tidak boleh menempatkan pekerja yang berumur kurang dari 18 (delapan belas) tahun di daerah pengendalian. ${ }^{8}$

Data yang digunakan pada kajian ini yaitu data sekunder dari hasil pemeriksaan kesehatan berkala tahun 2014-2015, dimana terdapat beberapa data hasil pemeriksaan laboratorium yang tidak lengkap yang mungkin disebabkan karena sampel darah tidak cukup untuk pemeriksaan laboratorium.

Data Hasil pemeriksaan leukosit menunjukkan bahwa jumlah leukosit semua petugas radiologi masih dalam batas normal. Hal ini sesuai dengan hasil penelitian yang dilakukan oleh Mayerni, dkk yang menyatakan bahwa kadar leukosit pekerja radiasi di tahun 2008-2010. ${ }^{7}$ Hasil pemeriksaan $\mathrm{Hb}$ menunjukkan ada peningkatan jumlah petugas yang mempunyai kadar $\mathrm{Hb}$ rendah dari 3 orang pada tahun 2014 menjadi 4 orang pada tahun 2015. Demikian juga pada pemeriksaan morfologi darah tepi, didapatkan yang mempunyai kesan anemia normositik meningkat dari dua petugas pada tahun 2014, menjadi 3 orang pada tahun 2015. Pada pemeriksaan serum besi ditemukan dua petugas yang mempunyai kadar serum besi yang rendah.

Sesuai hasil penelitian oleh Tur Rahardjo dan Siti Nlirhayati (2006) bahwa sebanyak $20,7 \%$ di antara pekerja radiasi kadar $\mathrm{Hb}$-nya menurun hingga $12 \mathrm{gr} / \mathrm{dl}$. Penurunan kadar $\mathrm{Hb}$ diduga bukan disebabkan karena paparan radiasi melainkan karena fisik pekerja yang menurun karena jumlah eritrositnya masih dalam batas normal. ${ }^{9}$

Efek radiasi terhadap tubuh manusia bergantung pada seberapa banyak dosis yang diberikan, dan bergantung pula pada lajunya, apakah diberikan secara akut (dalam jangka waktu seketika) atau secara gradual (sedikit demi sedikit). Selain bergantung pada jumlah dan laju dosis, setiap organ tubuh mempunyai kepekaan yang berlainan terhadap radiasi, sehingga efek yang ditimbulkan radiasi juga akan berbeda. ${ }^{1,2,3}$

RSPI Prof. Dr. Sulianti Saroso secara rutin telah melakukan pemantauan dosis pada para petugas radiologi. Rata-rata jumlah dosis yang diterima oleh petugas radiologi di RSPI Prof. Dr. Sulianti Saroso yaitu 1,1 $\mathrm{mSV} /$ tahun. Dosis radiasi tersebut masih berada dibawah Nilai Batas Dosis (NBD) yang ditentukan oleh BAPETEN. (NBD: $20 \mathrm{mSv})^{8,10,11}$ Hal ini sesuai penelitian yang dilakukan oleh Mayerni, 
dkk tentang dampak radiasi terhadap kesehatan pekerja radiasi menunjukkan bahwa seluruh pekerja radiasi pada tiga Rumah Sakit Kota Pekanbaru memperoleh paparan dosis yang normal atau masih dalam kategori aman. $^{7}$ Hal tersebut dimungkinkan karena petugas radiologi tersebut telah menerapkan perlindungan terhadap radiasi sesuai dengan kaidah proteksi radiasi serta didukung sarana dan prasarana yang sudah memenuhi syarat sesuai dengan peraturan yang telah ditetapkan, seperti: tersedianya alat proteksi radiasi, bangunan ruang radiologi menggunakan tabir pelindung dengan lapisan timbal $(\mathrm{Pb})$.

Rumah sakit wajib melakukan pemantauan dosis yang diterima pekerja radiasi dengan tujuan untuk memastikan bahwa dosis radiasi para petugas radiologi tidak melampaui NBD yang telah ditentukan oleh BAPETEN. Radiasi dapat membahayakan kesehatan, maka pemakaian radiasi perlu diawasi, baik melalui peraturanperaturan yang berkaitan dengan pemanfaatan radiasi dan bahan-bahan radioaktif. Instansi yang bertugas melaksanakan pengawasan melalui peraturan, perizinan, dan inspeksi terhadap segala kegiatan Pemanfaatan Tenaga Nuklir yaitu BAPETEN (Badan Pengawas Tenaga Nuklir). ${ }^{8,10,12}$

\section{Kesimpulan}

$\begin{array}{rrr}\text { Secara } & \text { keseluruhan } & \text { hasil } \\ \text { pemeriksaan } & \text { hematologi dan }\end{array}$ pemantauan dosis petugas radiologi masih dalam batas normal. Rumah sakit wajib melakukan pemeriksaan kesehatan pada para petugas radiologi yang meliputi pemeriksaan fisik dan laboratorium untuk memantau kondisi kesehatan petugas dan memastikan bahwa pekerja dalam kondisi sehat dalam menjalankan tugasnya. Salah satu cara untuk menghindari terjadinya paparan radiasi yaitu dengan melakukan pemantauan rutin dosis perorangan pekerja radiasi.

\section{Ucapan Terima Kasih}

Penulis mengucapkan terima kasih kepada institusi RSPI Prof. Dr. Sulianti Saroso, Dr. Vivi Lisdawati, MSi. Apt selaku Direktur Pengkajian Penyakit Infeksi dan Penyakit Menular dan semua pihak yang terlibat/berkontribusi dalam proses kajian ini.

\section{Daftar Pustaka}

1. Badan Pengawas Tenaga Nuklir. Efek Radiasi terhadap Manusia [Internet]. 2005. Available from: http://www.batan.go.id/pusdiklat/e learning/proteksiradiasi/pengenal an radiasi/2-3.htm

2. Sumarsono. Efek radiasi [Internet]. 2008. Available from: http://ssradiology.blogspot.co.id/2008/08/ efek-radiasi.html 
3. Rani M. Efek Radiasi Pengion terhadap Jaringan Tubuh [Internet]. 2014. Available from: http://anodakatoda.blogspot.co.id/ 2014/02/efek-radiasi-pengionterhadap-jaringan.html

4. Richardson DB, Cardis E, Daniels RD, Gillies M, Jacqueline A, Hagan $O$, et al. Risk of cancer from occupational exposure to ionising radiation: retrospective cohort study of workers in France , the United Kingdom, and the United States ( INWORKS ).

5. Thierry-chef I. Low doses of ionizing radiation increase risk of death from solid cancers Low doses of ionizing radiation increase risk of death from solid cancers. 2015;(October):1-2.

6. Sulaeman ES. Analisis Pemaparan Radiasi Terhadap Profile Hematologi Pekerja Radiasi Divisi Radiologi Rumah Sakit Dr. Kariadi Semarang. Universitas Diponegoro; 2003.

7. Mayerni, Ahmad A, Abidin Z. Dampak Radiasi Terhadap Kesehatan Pekerja Radiasi di Rsud Arifin Achmad, Rs Santa Maria Dan Rs Awal Bros Pekanbaru. J Ilmu Lingkung. 2013;7(1):114-27.

8. Badan Pengawas Tenaga Nukllir Republik Indonesia. Peraturan Kepala Badan Pengawas Tenaga Nuklir Nomor 4 tahun 2013 tentang Proteksi dan Keselamatan Radiasi dalam Pemanfaatan Tenaga Nuklir. 2013.

9. Rahardjo T, Nlirhayati S. Pemeriksaan Hematologi pada pekerja radiasi. In presentasi ilmiah fungsional teknis non peneliti, 18 desember 2006.ISSN: 1410-5381; 2006. p. 22-31.
10. Badan Pengawas Tenaga Nuklir RI. Peraturan Kepala Badan Pengawas Tenaga Nuklir Nomor 6 Tahun $2010 \quad$ Tentang Pemantauan Kesehatan Untuk Pekerja Radiasi. 2010.

11. Badan Pengawas Tenaga Nukllir Republik Indonesia. Peraturan kepala Badan Pengawas Tenaga Nuklir Nomor 8 tahun 2011 tentang Keselamatan Radiasi Penggunaan Pesawat Sinar- $X$ Radiologi Diagnostik dan Intervensional. 2011.

12. Peraturan Pemerintah RI Nomor 33 tahun 2007 tentang Keselamatan Radiasi Pengion dan Keamanan Sumber Radioaktif.; 2007. 